\title{
Charting the Course for Sustainable Small Island Tourist Development
}

\author{
Teresa L. McKee
}

American Institute of Certified Planners, American Planning Association, Chicago, USA.

Email: TisaL@aol.com

Received December $13^{\text {th }}, 2012$; revised January $12^{\text {th }}, 2013$; accepted February $11^{\text {th }}, 2013$

\begin{abstract}
This article, Charting the Course for Sustainable Small Island Tourist Development, addresses sustainability criteria for small island tourist development drawing on the history of development in the last decade in the Bocas del Toro archipelago of the Republic of Panama in the Caribbean Sea near the border of Costa Rica. Tax deferments for the development of vacation and resort properties spurred a boom in this island locale since the late 1980's. Tourist Law 8 of the Panamanian constitution is referenced. Sustainability criteria of water supply and availability are suggested and outer island projects are discussed. Lessons are outlined and recommendations are made for permit qualifications that promote sustainable small island tourist development.
\end{abstract}

Keywords: Sustainable; Small; Island; Tourist; Development

\section{Introduction}

A general understanding of sustainable development is that which does not compromise the ability of future generations to "sustain" their quality of life similar to the pre-development quality the area has to offer. How realistic is that? Doesn't development by its very nature degrade some aspects of an area while offering new and different benefits to present and future generations? This is particularly true when applied to development in highly sensitive and fragile island environments with limited fresh water, land vulnerable to the vagaries of ocean tides and sea levels and depletion and renewal of native flora and fauna, especially of the rainforested islands, that are ancient and take decades to renew if de-forested for precious hardwoods [1].

\section{Environmental Review Considerations}

Does this result in cost/benefit analyses required for prospective small island development projects? In the Republic of Panama, in the late 1980's, the USA handed over control of the Panama Canal management [2]. That event combined with political upheaval there with the ousting of the dictator Manuel Noriega, led to a new democratically elected government in Panama that enacted a new constitution which included Tourist Law $8[3,4]$. This provision in the law was to entice developers and outside investors to build housing and tourist facilities to bolster the Panamanian economy. As a result, Panama had an infusion of capital and development, e.g. the Trump Ocean Club and numerous other residential and recreational high rise complexes in the downtown and ocean areas of Panama City and its shores in rural and island areas. The Bocas del Toro archipelago in the Caribbean Sea near the Costa Rican border is an example of the latter. In the rush to qualify for the benefits discussed below under the new tourist development provision, and with the lack then of local inspection manpower and lack of surveyed lands, many single properties were developed without cost/benefit analyses or detailed environmental review. This is especially true for individual "speculative" homes, built for sale to outside investors, ex-pats and entrepreneurs in the vacation and travel industries. With the passage of time, more scrutiny has been brought to bear with electrical and water made available for approved buildings and increased environmental regulations, especially for larger projects, have been enacted in Bocas del Toro and throughout the country.

Tourist development was initially welcomed in Bocas del Toro as a needed infusion of capital having experienceda loss of agricultural revenue. Historically, the town of Bocas del Toro was a colonial outpost and center for banana cultivation. Many Bocas families of today are descendants of Jamaican laborers brought to Bocas to work in the banana industry. When the banana blight decimated the plantations in the archipelago in the midtwentieth century, the banana industry shifted to the 
Panamanian mainland where today Chiquita Banana is the major producer (see Stephens and Swain, Banana People [5] for United Fruit Company history). The tourist development spurred by Tourist Law 8 breathed new life into this Caribbean locale and brought with it environmental changes and concerns [1].

\section{Tourist Incentives for Sustainable Development}

In the late 1990's, during the Moscoso presidency, Panama enacted Tourist Law 8 [4], which provided investors with a tax-deferred home or project if offered for a vaca- tion rental when not occupied by the purchaser.

Many non-titled, right of possession homes are still being built and offered for sale throughout the Bocas archipelago. Some of these lands have recorded plot plans and now are advised to be listed in the Public Registry to protect the homeowner regardless of how the property is titled. Investors are encouraged to hold ownership via an offshore corporation as additional ownership protection and revenue shelter. In addition to enacting the law, the Moscoso legislature successfully passed laws that protected a significant number of acres (see CIA Factbook-Panama, 2000, [6]) for total acreage put in government preserves in that era) from future development providing motivation for building construction on owned lands not currently in preserves but foreseeing more regulations to follow.

Subsequent development of single, speculative, "spec" homes altered the island environment of Bocas del Toro putting a strain on the provision of potable water supplies, sewage treatment and garbage collection and resulted in deforestation of island native hardwoods for building lumber. Outer islands from Colon Island where the town of Bocas is located were significantly affected. Piped water was attempted and has gone through revisions as the town of Bocas has experimented with ways to submerge pipe that can withstand tidal pressures. Rain catchment for drinking water on outer islands has been encouraged since the pipe from Colon Island has not been reliable. Landfill and waste water treatment has expanded on Colon Island to accommodate the increase in population from the new development [7].

Large scale multi-family developments have been stalled in environmental review for many years. Two major ocean/hotel facilities have opened in Bocas recently after extensive reviews and set-backs. These latter tourist projects employ the local populace and support local businesses (see Bocas Breeze [7] for project histories, namely Solarte, Red Frog Beach Club and Playa de las Tortugas Resort). The benefits of employment and tourist revenue infusion into the local economy should be evaluated against the alterations to the pristine island rainforest environments that were untouched except for indigenous uses of the natural resources for hunting, foraging and fishing for sustenance (see Gordon, [8] for discussion of Amerindian cultures in Bocas del Toro).

\section{Sustainability Comes with Choices for the Future}

How do we put a price-tag on small island natural resource amenities and evaluate the trade-offs of allowing similar developments on virgin islands or more development on nearby existing sites? If development is allowed to progress unchecked, pristine islands will be a figment of our memory or imagination only. The dream of beaching a boat and exploring an undeveloped island will be just that, a dream only, unrealizable for future generations. The Robinson Crusoes of the future will have to consider other adventures and learn survival skills elsewhere. Currently, the islands of the Zapatilla Keys and Escudo de Veraguas near the Bocas del Toro archipelago serve that exploratory and adventure impulse- beautiful and pristine [1].

For the protection of Bocas indigenous peoples' reliance on fishing for their table, recreational fishing is only minimally offered to tourists during sea fairs and by private charter. This allows the tribes to have assurance of replenishing supplies of lobster, pargorojo and tuna to name a few species the Bocas del Toro waters offer [1].

\section{Key Criteria and Demand Issues for Sustainable Island Tourist Development}

The key criteria for allowing more small island tourist development is the availability of potable water. Rain catchment is only successful if there is enough rainfall to warrant the expense. Pipelines to outer islands are risky due to tidal pressures on submerged pipe. A second criteria of note is ease of access via natural harbors and beaches. Permits are now required in Panama for harbor and dock development. Coast guard patrols and rescue systems need to be required. Bocas del Toro is an international port of call for pleasure craft from the Caribbean and Gulf of Mexico ports docking at existing marinas on Colon and Careneroislands. Slip demand for safe harbor increases during hurricane season from June through October since the Bocas archipelago is south of most hurricane activity. More harbor development will most likely occur in Bocas del Toro as slip demand increases further with population and tourism growth in the Caribbean and the Gulf of Mexico.

An abundant fuel supply is critical for increases in population, tourism and boating. Almirante, on the Panamanian mainland coast, is the main fuel supplier for the Bocas area. Air transportation has increased with Air Panama now offering more commuter flights to and from the mainland. These trends will increase demand for fuel. 
Alternative energy sources such as solar, wind, biofuels and natural gas for generators should be developed. Sunny island areas should require solar and new generator technologies. The demand for housing, recreation and safe harbor will increase with population growth in tourist sectors seeking scuba, snorkeling, surfing, kayaking, bird watching and boat touring opportunities.

Water supply should be a requirement of permit issuance. Proof of future water supply is now being required of developers in some USA regions along with green building standards i.e. Leeds certification. The immediate effect of these requirements is an initial slow down of project completion as builders pencil out the provision of water and incorporation of green building products into their building budgets [9].

\section{Conclusions}

\subsection{Lessons and Recommendations for Sustainable Small Island Tourist Development}

What appears to be the lesson of the Bocas del Toro development pattern, is that further outermost islands are spared for now as it is much more costly to provide reliable electricity, water and food the further out at sea the island is located. So, channel your inner Crusoe in regard to outer island development and leave them untouched for future generations to explore. That is true sustainability in the purest sense. Encourage rain water catchment in all developments. Additionally, require re-planting of hardwoods used for development. Address cultural concerns of island populations, both indigenous and histori$\mathrm{cal}$, to incorporate local benefits into any development especially with regard to housing and employment. Require major developers to offer improvements in education and medical services to off-set perceived and real negative impacts to local populations and the environment. Create marine and land preserves to leave some marine and land areas pristine for the environmental health of the area. Do cost/benefit analyses, visioning and charettes to create a context for the community to choose appropriate development paths, specifying goals, objectives, options and priorities. Create tax-deferred development incentives in local and national codes that are tied to mandated requirements enumerated above for permit qualification.

\subsection{Consider No Development on Some Islands to Maximize Sustainability}

No development is a choice that offers that wild, exploratory area and protects island flora and fauna the most. Consider doing nothing to an island. Protect that Crusoe dream and that survivor and indigenous experience for future generations. Have you tried a coconut lately?

\section{REFERENCES}

[1] T. McKee, (Teresa L. McKee, AICP), The Notebook of Isla Carenero, Volume One, McKee House, 2000-2010, a Compilation of Articles, Excerpts, Author Material, Planning Meeting Notes, Letters).

[2] D. McCullouch, "The Path between the Seas," Simon \& Schuster, New York City, 1978.

[3] G. R. Evans, “The Panama Canal Treaty Swindle,” Fulton-Hall Publishing Company, San Francisco, 1999.

[4] Constitution of the Republic of Panama, 2000, Tourist Law 8.

[5] C. S. Stephens and R. Swain, In: Banana People, 2002, pp. 258-266.

[6] CIA Factbook-Panama, 2000.

[7] The Bocas Breeze, January-December, 2005-2011/for Bocas History-July 2008, Vol. 5, Issue 7.

[8] B. L. Gordon, “A Panama Forest and Shore,” Boxwood Press, New York, 1983.

[9] American Planning Association, “Planning," Vol. 73, 2012. 